\title{
Changes of Total Phenolics, Tannins, Phytate and Antioxidant Activity of Two Sorghum Cultivars as Affected by Processing Sorour, M.A. ${ }^{1}$; A. E. Mehanni ${ }^{1}$; E. M. Taha ${ }^{2}$ and A. K. Rashwan ${ }^{2}$ ${ }^{1}$ Food Science and Nutrition Dept. Faculty of Agriculture, Sohag University, Sohag, Egypt. \\ ${ }^{2}$ Food Science and Dairy Dept. Faculty of Agriculture, South Valley University, Qena, Egypt.
}

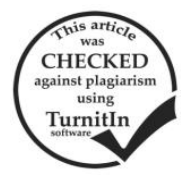

\section{ABSTRACT}

Sorghum (Sorghum bicolor (L.) Moench) is a rich source of bioactive compounds such as polyphenols, tannins, and phytate. Polyphenols have been recognized as the most abundant source of anti-oxidants in our diet. The quantity and quality of polyphenols, tannins and phytate in foods are affected by processing due to their highly reactive nature, which may affect their anti-oxidant activity and the nutritional value of foods. The aim of the present study was to investigate how some domestic processing methods such as soaking (in different solutions), germination, fermentation using (Saccharomyces cerevisia) and wet cooking influence phenolic compounds, tannins, phytate content and free radical scavenging activity of two sorghum cultivars \{high tannin sorghum (Assuit 14) and low tannin sorghum (Giza 15)\} grown in southern Egypt. The results indicated that soaking in (distilled water, $\mathrm{KOH} 2 \%, \mathrm{NH}_{4} \mathrm{OH} 30 \%$, and $\mathrm{NaOH} 2 \%$ ), and germination had significant reduction of total phenolic, tannin and, phytic acid content and antioxidant activity. While fermentation process of Giza 15 increased the total phenolic content and the antioxidant activity of the fermented flour, while a significant decrease of tannin and phytic acid was found. On the other hand, wet cooking treatment for $2 \mathrm{~h}$ of Giza 15 grains showed an increase of antioxidant activity (58\%), and a decrease in phytic acid, phenolic compounds and tannins contents. Our results illustrated that sorghum Assiut 14 had higher content of phenolics, tannins, phytate as well as antioxidant activity by DPPH than Giza 15. For $\left(\mathrm{IC}_{50}\right)$ Assuit 14 had 7.544 while Giza15 had 22.147. All processing methods affect on phenolics, tannin and,phytic acid content and activities of antioxidant components of sorghum differentially, suggesting that treating the seed before use is able to change the bioactive compounds content of sorghum and the antioxidant activity as related.

Keywords: Processing, Phenolic compounds, phytic acid, Tannin, Antioxidant activity, Sorghum grains.

\section{INTRODUCTION}

The plants kingdom is considered a major food source for humans in the worldwide especially cereal. After wheat, rice, maize and barley sorghum ranks fifth of important cereals concerning world production. Also it is very important source of food for peoples in the semi and tropics of Asia and Africa (Awika et al., 2003a; FAO 2005 and Liu et al., 2012). sorghum is found in Upper Egypt. Sorghum contains valuable amount of protein $(7.5-10.8 \%)$, oil (3.4-3.5\%), ash $(1.2-1.8 \%)$, fiber $(2.3-2.7 \%)$ and carbohydrates $(71.4$ $80.7 \%$ ) with a dry matter ranged from 89.2 to $95.3 \%$, depending on type of cultivar (Rahaman et al.,2005).

It has been suggested that antioxidants may contribute to the health benefits of cereal-based foods by reducing the incidence of aging-related chronic diseases including heart diseases and some types of cancer (Miller et al., 2000).

As other cereals, sorghum also is an important source of bioactive compounds such as 3deoxyanthocyanidins, tannins, vitamin E, carotenoids, and other antioxidants (Awika and Rooney 2004). These compounds reduce the damage caused by free radicals and thus promote benefits to human health (Valko et al., 2007).

Antioxidant compounds of sorghum such as phenolic compounds, tannins and phytate provide protection against a variety of cancers mediated through antioxidation properties (Oboh 2006 ; Dykes and Rooney 2007; Goufo and Trindade 2014).

Tannins are known for their effects as antioxidants at the same time tannins are related with reducing protein digestibility (Duodu et al., 2002) that could be related to their ability for enzymes inhibition(Scalbert et al., 2000). However, like other cereals, sorghum grains need to be processed before human consumption, which may modify their chemical composition, and functional and nutritional value. Some processing employed to improve the organoleptic, nutritional and antioxidant properties of sorghum include soaking, cooking, germination and fermentation. Soaking, germination and pressure-cooking proved to be effective household strategies to reduce the levels of polyphenols and tannins in grains (Shweta et al., 2010) that led to improvement for both product color and digestibility. The negative effect of sorghum tannins could be reduced by some procedures like alkali treatment. (Beta et al.1999). Some reports exist on antioxidant activity of fully processed products like cookies and bread containing sorghum bran, as well as extrusion cooked products (Awika et al., 2003b).

The aim of our study was to study the effect of phenolics, tannins and phytic acid on the antioxidant activity of tow sorghum varieties and to determine the effect of different domestic process on these active compounds and on the antioxidant

\section{MATERIALS AND METHODS}

\section{Materials}

The samples of sorghum cultivars (Sorghum bicolor (L.)Moench); low tannin (Giza 15) and high tannin (Assiut 14) samples were obtained from Agriculture Research Center at Shandawel, Sohag, Egypt, Season 2013.

All chemicals used in this study obtained from Alpha Chemicals Company and Sigma - Aldrich Company.

\section{Technological Methods}

Sorghum grains soaking:

Sorghum seeds soaked by using distilled water ( $1: 5 \mathrm{w} / \mathrm{v}$ ) for $20 \mathrm{~h}$ (Afify et al.,2011), and were soaked in various alkali solutions $(2 \% \mathrm{KOH}$ for $20 \mathrm{~h}, 30 \% \mathrm{NH} 4 \mathrm{OH}$ for $20 \mathrm{~h}$ and $2 \% \mathrm{NaOH}$ for $10 \mathrm{~h}$ ) the soaked seeds were maintained at $4{ }^{\circ} \mathrm{C}$. At the end of soaking period, seeds were washed with distilled water to remove residual soaking solution (Mulimani and Supriya 1994). After that, 
the seeds were dried and milled using a blender home mill (Moulinex blenders) to get fine flour that was kept at $-4^{\circ}$ $\mathrm{C}$ until analysis.

\section{Germination of sorghum grains:}

Sorghum seeds were germinated according to the method of (Elkhalifa and Bernhardt 2010). The sorghum grains $(50 \mathrm{~g})$ steeped in distilled water for $20 \mathrm{~h}$ with two changes of water during the day. The wet sorghum is placed inside Petri dishes with cotton saturated with distilled water for $12 \mathrm{~h}$. The germinated grains were dried and milled in a blender home mill (Moulinex blenders) to obtain fine flour and kept at $-4^{\circ} \mathrm{C}$ until analysis.

\section{Fermentation of sorghum flour:}

Sorghum flour was fermented according to the traditional method practiced described by (El Tinay et al., 1979 ; Chinedu et al.,2010). The flour was mixed with distilled water $(45 \% \mathrm{w} / \mathrm{v})$ in a plastic bucket covered with a lid, kneaded into dough, and allowed to ferment using yeast (Saccharomyce scerevisiae) and incubated at $40^{\circ} \mathrm{C}$ for $12 \mathrm{~h}$. The fermented dough was dried and ground to flour then stored in polyethylene bags at $-4^{\circ} \mathrm{C}$ prior to analysis.

\section{Cooking of sorghum grains:}

According to (Duodu et al.,2002) $50 \mathrm{~g}$ of sorghum seeds were boiled in distilled water $(1: 5 \mathrm{w} / \mathrm{v})$, for $2 \mathrm{~h}$ with stirring that followed by submerring with distilled water, the cooked seeds were dried and milled to get fine flour then kept at $-4^{\circ} \mathrm{C}$ for further analysis.

\section{Analytical Methods}

\section{Gross Chemical Composition:}

Moisture, crude fat, crude protein, fiber ash and minerals (Magnesium, calcium, iron, and zanic) contents were determined according to (AOAC 2005). Total carbohydrate content of grains was calculated by difference.

Determination of phenolics content (PCs):

The total phenolic content in sorghum seeds or sorghum flour were extracted by using $0.3 \%$ acidified methanol water 60:40 in ultrasonic (Digital Ultrasonic Cleaner Bath, Item Code 100405-230, Model : 405) and were determined using the Folin-Ciocalteau method with slight modification (Taga et al.,1984). Using FolinCiocalteu method. Absorbance was measured at $750 \mathrm{~nm}$ against a blank. Gallic acid was applied to construct the standard curve (Spectrophotometer,SP-2000UV).

Tannin assay:

The content of tannin of sorghum before and after treatments were assayed by the vanillin- $\mathrm{HCl}$ method (Price et al.,1978) with modification. The results were prepared as catechin equivalents, i.e. amount of catechin Table 1. Gross chemical composition of sorghum grains (on dry weight basis).

\begin{tabular}{|c|c|c|c|c|c|c|c|c|c|c|c|c|c|}
\hline Sorohum & Crude & Crud & Ash & Moisture & fibers & Carbohydrate & & & Miner & als $\mathrm{mg} / 1$ & $0 \mathrm{~g}$ & & \\
\hline Cultivars & $\begin{array}{l}\text { Protein } \\
\% \%\end{array}$ & fat $\%$ & $\%$ & $\%$ & $\begin{array}{c}\% \\
\text { Crude }\end{array}$ & & $\mathbf{P}$ & Ca & Mg & $\mathbf{N a}$ & $\mathbf{K}$ & $\mathbf{F e}$ & Zn \\
\hline$\overline{\text { Giza } 15}$ & 12.7 & 3.7 & 1.55 & 7.55 & 1.54 & 80.51 & 314.5 & 197.8 & 123 & 1535.9 & 235.2 & 27 & 8.3 \\
\hline Assuit 14 & 12.5 & 3.7 & 1.85 & 6.86 & 2.54 & 76.43 & 414.3 & 229.4 & 138.1 & 1214.9 & 299.4 & 20 & 6.8 \\
\hline
\end{tabular}

*Means of triplicates.

Data of minerals average values revealed that sodium was the predominate element present in all grains. phosphorus, potassium, calcium, magnesium, ferric (iron) (60mgcatechin / 100mL absolute methanol) which gives a colour intensity equivalent to that given by tannins after correcting for blank, the absorption was measured at 500 $\mathrm{nm}$ by spectrophotometer. Then tannin content (mg $\mathrm{CE} / 100 \mathrm{~g}$ ) was calculated according to the equation:

$\mathrm{C} \times$ volume extracted

Catechin equivalent(Tannin)mg/100g $=\overline{\text { Dry sample weight }} \times(\mathrm{g})^{100}$

Where $\mathrm{C}$, concentration obtained from the calibration curve $(\mathrm{mg} / \mathrm{mL})$.

\section{Determination of phytate:}

Phytate content was determined according to (AOAC 1990) with some modification by (Sorour et al., 2003). Dowex ${ }^{\circledR} 50$ WX 8 hydrogen form hydrogen form, 200-400 mesh, and phytic acid was determined from the standard curve according to the equation:

Phytic acid $(\mathrm{mg} / 100 \mathrm{~g}$ dw $)=$ Phytate $P \times 3.446$. Determination of antioxidant activity :

The method described by (Hatano et al.,1988) with some modifications used for the determination of the antioxidant activity stable DPPH radical. The decrease in absorbance was measured at $517 \mathrm{~nm}$ against a blank without extract with a spectrophotometer. From a calibration curve obtained with different amounts of extract the $\mathrm{IC}_{50}$ was calculated. The $\mathrm{IC}_{50}$ was that concentration of an antioxidant which was required to quench $50 \%$ of the initial DPPH radicals under the experimental conditions given.

Statistical analysis:

Data analysis was performed using the SAS software (version 9.1, SAS Institute). Mean separation of data was carried out using least significant difference Duncan's test at 5\% and probability levels.

\section{RESULTS AND DISCUSSION}

\section{Chemical composition:}

The results in Table (1) show the chemical composition of the studied sorghum grains cultivars. The content of crude protein, fat, fiber, ash and carbohydrates vary depending on the type of sorghum grains cultivar. Crude protein content ranged between $(12.5-12.7 \%)$ while crude fat content was $3.7 \%$ for both varieties, ash content was (1.55 and $1.85 \%)$, moisture (7.55 and 6.86\%), crude fiber (1.54 and $2.54 \%$ ) and carbohydrates (80.51 and $76.43 \%$ ) for Giza 15 and Assuit14 cultivar, respectively. Sorghum acts as a principal source of energy, protein, vitamins and minerals for millions of the poorest people living in Africa, Asia and the semi-arid tropics worldwide (Klopfesntein and Hoseney 1995). and zinc were present by sensible amount in all grains under investigation. Processed sorghum seeds or flour were found to be important sources of calories and proteins to 
the vast majority of the population as well as for poultry and livestock (FAO 1997).

Total phenolics content.

The results presented in Tables $(2 \& 3)$ show the affect of different processing on phenolics content of sorghum cultivars. The phenolics contents were 178.28 and $825.36 \mathrm{mg}$ gallic acid equivalent (GAE)/100g raw sample of Giza 15 (low sorghum tannin) and Assuit 14 (high tannin sorghum), respectively. The results of phenolic content are in the same trend with that of (Dykes 2008) who reported that total phenol contents of low and high sorghum tannin varied from 180 to $600 \mathrm{mg}$ and from 800 to $2000 \mathrm{mg}$ (GAE/100g ),respectively. All soaking, germination and wet cooking procedures showed significant decreases for total phenolics content. The high reduction levels of phenolics content in sorghum(Giza15) grains were showed after soaking in water (43.4\%) and in $\mathrm{NH}_{4} \mathrm{OH} 30$. However,these losses were more in sorghum (Assiut 14)grains varied from 61.0 to $73.0 \%$ after soaking in $\mathrm{NaOH} 2 \%$ and $\mathrm{NH}_{4} \mathrm{OH}$ $30 \%$,respectively. The reduction of phenolic compounds after soaking in different solution may be to loss with soaking solution. The results approved with (Afify et al.,2012), who found that the loss of total phenols ranged between $21.97 \%$ and 28.30 in sorghum after treatments and who reported that this loss was expected as the effect of soaking in the removing of the phenolic compounds. The reduction in phenolics as a result of alkali soaking might also be due to abstraction of hydrogen atoms and rearrangements of the structures, which affecting mainly the phenolic groups. (Kennedy et al.,1984; Cilliers and Singleton 1990). They also reported that, a minor part of the phenolic degradation after alkali soaking might have been caused by the possible opening of the C-ring and rearrangements to other products. Germination of Giza 15 and Assuit 14 for 38hreduced the phenolics content by 23.9 and $48.8 \%$ respectively. The decrease in phenolics content after germination could be the water-soluble compounds, that are found in the pericarp and testa leached out in the water (Awika and Rooney2004; Beta et al.,1999 ; Waniska 2000), or a new insoluble complexes with proteins could be formed. (Riedl and Hagerman 2001).Wet cooking for $2 \mathrm{~h}$ led to total phenols losses of 32.3 and $32.2 \%$ in Giza 15 and Assuit 14respectively, of their initial values of sorghum grains. Total phenolic content significantly decreased during cooking (Table 3). The reactive hydroxyl groups of phenolic compounds may have reacted, or created insoluble complexes with food components such as protein or minerals, or even more polymerised into condensed phenolics that led to a decrease of measured phenolic hydroxylic groups. (Barroga et al.,1985). On the other hand, fermentation of Giza 15 flour for $12 \mathrm{~h}$ increased phenolic compounds by $31.8 \%$, but Assuit 14 was loss 3.8\%. (Katina et al.,2007) explained the increase on total phenolic content after fermentation by the fact that metabolic activity of microbes during fermentation process could change the active compounds level, or could breakdown the structural of cereal cell walls that led to liberation and/or synthesis of numerous bioactive compounds during fermentation, enzymes such as amylases, xylanases and proteases derived from the grain and microbes contribute to the modification of grain composition (Katina et al., 2007; Loponen et al., 2004).

Table 2. Effect of soaking on phenolics content in sorghum grains.

\begin{tabular}{|c|c|c|c|c|c|c|c|c|c|}
\hline \multirow[b]{2}{*}{$\begin{array}{l}\text { Sorghum } \\
\text { Cultivars }\end{array}$} & \multicolumn{9}{|c|}{ Phenolic content (mg GAE/100g dw). } \\
\hline & $\begin{array}{c}\text { Control } \\
\text { T0 }\end{array}$ & $\begin{array}{c}\text { Soaking } \\
\text { in water } \\
\text { T1 }\end{array}$ & $\begin{array}{c}\% \\
\text { Reduction }\end{array}$ & $\begin{array}{c}\text { Soaking in } \\
\text { KOH 2\% } \\
\text { T2 }\end{array}$ & $\begin{array}{c}\% \\
\text { Reduction }\end{array}$ & $\begin{array}{c}\text { Soaking in } \\
\text { NH4OH } 30 \\
\% \\
\text { T3 }\end{array}$ & $\begin{array}{c}\% \\
\text { Reduction }\end{array}$ & $\begin{array}{c}\text { Soaking in } \\
\text { NaOH } \\
2 \% \mathrm{~T} 4\end{array}$ & $\begin{array}{c}\% \\
\text { Reduction }\end{array}$ \\
\hline$\overline{\text { Giza } 15}$ & $178.28^{b}$ & $100.89^{I}$ & 43.41 & $171.01^{\mathrm{c}}$ & 4.08 & $102.20^{\mathrm{I}}$ & 42.70 & $168.51^{\mathrm{c}}$ & 5.50 \\
\hline Assuit 14 & $825.36^{\mathrm{a}}$ & $266.86^{\mathrm{g}}$ & 67.70 & $308.20^{\mathrm{t}}$ & 62.66 & $222.92^{\mathrm{h}}$ & 73.00 & $321.5^{\mathrm{e}}$ & 61.0 \\
\hline
\end{tabular}

Values in the same row bearing different sidescripts are significantly ( $\boldsymbol{p \leq 0 . 0 5 )}$ different(as assessed by Duncan's multiple range test).

Table 3. Effect of germination, fermentation and wet cooking on phenolics content in sorghum.

\begin{tabular}{lccccccc}
\hline \multirow{2}{*}{$\begin{array}{l}\text { Sorghum } \\
\text { Cultivars }\end{array}$} & $\begin{array}{c}\text { Control } \\
\text { T0 }\end{array}$ & $\begin{array}{c}\text { Germination } \\
\text { for 38h } \\
\text { T5 }\end{array}$ & $\begin{array}{c}\text { Phenolic content (mg GAE/100g dw). } \\
\text { Reduction }\end{array}$ & $\begin{array}{c}\text { Fermentation } \\
\text { for 12h } \\
\text { T6 }\end{array}$ & $\begin{array}{c}\text { \% } \\
\text { Reduction }\end{array}$ & $\begin{array}{c}\text { Wet cooking } \\
\text { for 2h T7 }\end{array}$ & $\begin{array}{c}\text { \% } \\
\text { Reduction }\end{array}$ \\
\hline Giza 15 & $178.28^{\mathrm{b}}$ & $135.7^{\mathrm{d}}$ & 23.9 & $234.89^{\mathrm{a}}$ & $31.8(+)$ & $120.67^{\mathrm{e}}$ & 32.3 \\
Assuit 14 & $825.36^{\mathrm{a}}$ & $426.07^{\mathrm{d}}$ & 48.4 & $793.796^{\mathrm{b}}$ & 3.8 & $486.08^{\mathrm{c}}$ & 41 \\
\hline Vyyyyyyy
\end{tabular}

Values in the same row bearing different sidescripts are significantly $(p \leq 0.05)$ different(as assessed by Duncan's multiple range test).

\section{Tannin content:}

Tables (4\&5) showed the effect of different process on sorghum tannins content. The tannin contents in Assuit 14(high tannin sorghum ) had $1302.588 \mathrm{mg}$ catechin equivalent (CE)/100g sample while Giza 15(non tannin sorghum ) had $3.5793 \mathrm{mg}$ catechin equivalent (CE)/100g. Sorghums with a pigmented testa have tannins (Awika and Rooney 2004 ;Hahn et al., 1984). Soaking in distilled water, $\mathrm{KOH} 2 \%, \mathrm{NH} 4 \mathrm{OH} 30 \%, \mathrm{NaOH} 2 \%$, germination, fermentation and cooked processes showed significant decrease in tannin content $(\mathrm{P} \leq 0.05)$. Soaking in all alkali solutions was effective in removing considerable amount of tannins in both high and low tannin sorghum varieties tested in this study that arrived to not detected amount for both sorghum varieties. The tannin content lost during sorghum soaking in distilled water, $\mathrm{KOH} 2 \%, \mathrm{NH} 4 \mathrm{OH} 30 \%$ and $\mathrm{NaOH} 2 \%$ was 100 and $97.7 \%, 100$ and $100 \% ; 100$ and $99.6 \% ; 100$ and $100 \%$ for Giza 15 and Assiut 14 grains, respectively. The reduction of tannins after soaking in different solution may be due to removing of tannins by washing in the soaking solution. These results are in accordance with recorded by (Mulimani and Supriya 1994 ; Afify et al.,2012) who reported that the reduction of tannin by soaking may be due to the effect of soaking in the tannin removal. (Babar et al.,1988) observed that overnight soaking of jack bean seeds in $2 \% \mathrm{NaHCO}_{3}$ removed considerable amounts of tannic acid. 
Sorour, M. A. et al.

Table 4. Effect of soaking on tannins content in sorghum.

\begin{tabular}{|c|c|c|c|c|c|c|c|c|c|}
\hline \multirow[b]{2}{*}{$\begin{array}{l}\text { Sorghum } \\
\text { Cultivars }\end{array}$} & \multicolumn{9}{|c|}{ Tannins content (mg catechin equivalent $(\mathrm{CE}) / \mathbf{1 0 0 g}$ ) } \\
\hline & $\begin{array}{c}\text { Control } \\
\text { T0 }\end{array}$ & $\begin{array}{l}\text { Soaking in } \\
\text { water } \mathrm{T} 1\end{array}$ & $\begin{array}{c}\% \\
\text { Reduction }\end{array}$ & $\begin{array}{c}\text { Soaking in } \\
\text { KOH } 2 \% \\
\text { T2 }\end{array}$ & $\begin{array}{c}\% \\
\text { Reduction }\end{array}$ & $\begin{array}{c}\text { Soaking in } \\
\text { NH4OH } \\
30 \% \\
\text { T3 }\end{array}$ & $\begin{array}{c}\% \\
\text { Reduction }\end{array}$ & $\begin{array}{c}\text { Soaking in } \\
\mathrm{NaOH} 2 \% \\
\mathrm{~T} 4\end{array}$ & $\begin{array}{c}\% \\
\text { Reduction }\end{array}$ \\
\hline Giza 15 & $3.5793^{\mathrm{a}}$ & $\mathrm{ND}^{\mathrm{b}}$ & & $\mathrm{ND}^{\mathrm{b}}$ & & $\mathrm{ND}^{\mathrm{b}}$ & & $\mathrm{ND}^{\mathrm{b}}$ & \\
\hline Assuit 14 & $1302.588^{\mathrm{a}}$ & $29.542^{\mathrm{e}}$ & 97.7 & $N^{f}$ & & $5.194^{\mathrm{f}}$ & 99 & $N^{f}$ & \\
\hline
\end{tabular}

ND= Not Detected

Values in the same row bearing different sidescripts are significantly $(p \leq 0.05)$ different(as assessed by Duncan's multiple range test).

Also after fermentation, tannins were decreased in Giza 15 flour by $100 \%$, and in Assuit 14 flour by $48.6 \%$, wherase during grains germination for $38 \mathrm{~h}$. The reduction was $100 \%$ and $27.8 \%$.respectively for both varieties. The wet cooking process also caused a significant reduction in tannin content for both varieties this reduction were $100 \%$ for Giza 15 and $91.9 \%$ for Assuit 14 of their initial values of sorghum grains. After fermentation, tannins were decreased may be as a result of microbial activity during fermentation like tannase enzyme and metabolic for microbial fermentation. These results approved with (Abdelhaleem et al.,2008 and Rahman and Osman 2011). These results agree with that of (Abdelhaleem et al.,2008) Tannin content reduced by $68 . \mathrm{s} 0 \%$ and $74.5 \%$, respectively for both (high and low tannin) cultivars using natural fermentation. While the reduction of tannins after cooking may be a result of complexes tanins with sorghum grain components such as protein. Prolamins (proteins with high proline content) bind strongly with sorghum tannins. (Emmambux and Taylor2003). In the aqueous media polymerization process of tannins occurs between some pigmentes such as anthocyanins and with tennin molecule. (Remy et al.,2000), vanillin- $\mathrm{HCl}$ method could not be able to detect such as those complexes.

Table 5. Effect of germination, fermentation and wet cooking on tannins contents in sorghum

\begin{tabular}{|c|c|c|c|c|c|c|c|}
\hline \multirow[b]{2}{*}{$\begin{array}{l}\text { Sorghum } \\
\text { Cultivars }\end{array}$} & \multicolumn{7}{|c|}{ Tannins content (mg catechin equivalent (CE)/100g) } \\
\hline & $\begin{array}{c}\text { Control } \\
\text { T0 }\end{array}$ & $\begin{array}{c}\text { Germination for } \\
\mathbf{3 8 h} \\
\text { T5 }\end{array}$ & $\begin{array}{c}\% \\
\text { Reduction }\end{array}$ & $\begin{array}{c}\text { Fermentation } \\
\text { for } 12 \mathrm{~h} \\
\text { T6 }\end{array}$ & $\begin{array}{c}\% \\
\text { Reduction }\end{array}$ & $\begin{array}{c}\text { Wet Cooking } \\
\text { for } 2 \mathrm{~h} \\
\text { T7 }\end{array}$ & $\begin{array}{c}\% \\
\text { Reduction }\end{array}$ \\
\hline Giza 15 & $3.5793^{\mathrm{a}}$ & $\mathrm{ND}^{\mathrm{b}}$ & & $\mathrm{ND}^{\mathrm{b}}$ & & $\mathrm{ND}^{\mathrm{b}}$ & \\
\hline Assuit 14 & $1302.588^{\mathrm{a}}$ & $940.288^{\mathrm{b}}$ & 27.8 & $669.176^{\mathrm{c}}$ & 48.6 & $105.83^{\mathrm{d}}$ & 91.9 \\
\hline
\end{tabular}

Values in the same row bearing different sidescripts are significantly ( $\boldsymbol{p \leq 0 . 0 5 )}$ different(as assessed by Duncan's multiple range test).

Phytic acid

The effect of soaking in water, $\mathrm{KOH} 2 \%$, $\mathrm{NH} 4 \mathrm{OH} 30 \%, \mathrm{NaOH} 2 \%$, germination, fermentation and cooking on Phytic acid content for Giza 15 and Assuit 14 sorghum is shown in Tables( 6 \& 7). Phytic acid content in raw sorghum Giza 15 and Assuit 14 were 160.88 and $215.5 \mathrm{mg} / 100$, respectively. The high tannin sorghum (Assiut 14)occurred high reduction ability during all processing compared to low tannin sorghum(Giza 15). The ascending order of reduction being: water soaking $(6.7 ; 16.5 \%)$; soaking in $\mathrm{KOH} 2 \%$ $(7.8 ; 18.5 \%)$; soaking in $\mathrm{NaOH} 2 \%(11.7 ; 18.8 \%)$; Soaking in $\mathrm{NH} 4 \mathrm{OH} 30 \%(11.7 ; 23.6 \%)$; wet cooking $(12.7 ; 25.9 \%)$; germination $(13.6 ; 26.4 \%)$ and $36 \mathrm{~h}$ fermentation $(15.6 ; 28 \%)$.

Table 6. Effect of soaking on phytate in sorghum.

\begin{tabular}{lccccccccc}
\hline & \multicolumn{7}{c}{ Phytate content (mg/ 100g) } \\
\cline { 2 - 10 } Sorghum \\
Cultivars & $\begin{array}{c}\text { Control } \\
\text { T0 }\end{array}$ & $\begin{array}{c}\text { Soaking } \\
\text { in water } \\
\text { T1 }\end{array}$ & $\begin{array}{c}\text { \% } \\
\text { Reduction }\end{array}$ & $\begin{array}{c}\text { Soaking } \\
\text { in KOH 2 } \\
\text { \% }\end{array}$ & $\begin{array}{c}\text { \% } \\
\text { T2 }\end{array}$ & $\begin{array}{c}\text { Soaking in } \\
\text { Reduction }\end{array}$ & $\begin{array}{c}\text { NHOH 30 \% } \\
\text { T3 }\end{array}$ & $\begin{array}{c}\text { Soaking in } \\
\text { Reduction }\end{array}$ & $\begin{array}{c}\text { NaOH 2\% } \\
\text { T4 }\end{array}$ \\
\hline Reduction \\
Giza 15 & $160.88^{\mathrm{a}}$ & $150.11^{\mathrm{b}}$ & 6.7 & $148.33^{\mathrm{b}}$ & 7.8 & $142.123^{\mathrm{c}}$ & 11.7 & $141.99^{\mathrm{c}}$ & 11.7 \\
Assuit 14 & $215.486^{\mathrm{a}}$ & $179.97^{\mathrm{b}}$ & 16.5 & $175.59^{\mathrm{c}}$ & 18.5 & $164.552^{\mathrm{d}}$ & 23.6 & $174.974^{\mathrm{c}}$ & 18.8 \\
\hline
\end{tabular}

Values in the same row bearing different sidescripts are significantly ( $\mathbf{s} \mathbf{0 . 0 5})$ different(as assessed by Duncan's multiple range test).

Table 7. Effect of germination, fermentation and wet cooking on phytate in sorghum

\begin{tabular}{lccccccc}
\hline \multirow{2}{*}{$\begin{array}{l}\text { Sorghum } \\
\text { Cultivars }\end{array}$} & $\begin{array}{c}\text { Control } \\
\text { T0 }\end{array}$ & $\begin{array}{c}\text { Germination for } \\
\text { 38h T5 }\end{array}$ & $\begin{array}{c}\text { \% } \\
\text { Reduction }\end{array}$ & $\begin{array}{c}\text { Fermentation } \\
\text { for 12h T6 }\end{array}$ & $\begin{array}{c}\text { \% } \\
\text { Reduction }\end{array}$ & $\begin{array}{c}\text { Wet Cooking } \\
\text { for 2h T7 }\end{array}$ & $\begin{array}{c}\text { \% } \\
\text { Reduction }\end{array}$ \\
\hline Giza 15 & $160.88^{\mathrm{a}}$ & $138.94^{\mathrm{dc}}$ & 13.6 & $135.72^{\mathrm{d}}$ & 15.6 & $140.46^{\mathrm{c}}$ & 12.7 \\
Assuit 14 & $215.49^{\mathrm{a}}$ & $158.59^{\mathrm{e}}$ & 26.4 & $154.91^{\mathrm{f}}$ & 28 & $159.63^{\mathrm{e}}$ & 25.9 \\
\hline
\end{tabular}

Values in the same row bearing different sidescripts are significantly $(p \leq 0.05)$ different(as assessed by Duncan's multiple range test).

The reduction in phytic acid caused by soaking may be due to water solubilization of some phytic acid salts. Germination of sorghum resulted in a substantial reduction of phytic acid content. This substantial reduction of phytic acid content in germinated sorghum seeds may be due to the activity of the enzyme phytase, which hydrolyses phytic acid to inorganic phosphate and inositol (Eskin and Wiebe 1983). The reduction due to fermentation observed in this study was higher than other treatments. Enzymatic hydrolysis of phytic acid by endogenous phytase of sorghum and/or by phytase which was produced by the microorganism, may 
account for most of the reduction of phytic acid during fermentation. The low $\mathrm{pH}$ of fermented product and temperature of fermentation may also provide favorable conditions for phytase activity. The reduction due to wet cooking may be caused by the limited activation of phytase enzyme during cooking and before its denaturation by heat. These observations indicate that enzymatic methods (malting and fermentation) for phytic acid reduction are more effective than physical methods (soaking and heating).

\section{Antioxidant activity:}

Results presented in Tables ( 8 \& 9) show the examined processing effect on sorghum antioxidant activity. High tannin sorghums had higher antioxidant activity than non-tannin sorghum grains $(\mathrm{p}<0.005)$ assayed by DPPH). The DPPH radical scavenging activity of Giza15 was $22.147 \%$ and of Assuit 14 was $7.544 \%$ for raw sorghum grains. All processing used in this study caused a significant decrease $(\mathrm{p}<0.005)$ in the antioxidant activity for both sorghum varieties expect the fermentation and wet cooking of Giza 15 caused an increase of the DPPH radical scavenging activity of the sample. The DPPH scavenging activity in sorghum was decreased during soaking period. It was decreased of the original value after soaking for $20 \mathrm{~h}$ in distilled water, Giza15 ( 83\%) Assuit 14 ( 434\%), during soaking in $\mathrm{KOH} 2 \%$ for $20 \mathrm{~h}$ Giza 15 was $47.5 \%$. Assuit 14 was $446 \%$, during soaking in $\mathrm{NH}_{4} \mathrm{OH} 30 \%$ for $20 \mathrm{~h}$ Giza 15 was $90.5 \%$. Assuit 14 was $403 \%$, during soaking inNaOH $2 \%$ for 10 h Giza 15 was $135 \%$. Assuit 14 was $327 \%$, during germination for $12 \mathrm{~h}$ Giza 15 was $21 \%$. Assuit 14 was $122 \%$, This decreased in antioxidants activity after soaking in different solution may be cause of loss some antioxidants components they found in the raw sorghum grain like that phenolic compounds, tannins, phytate, caused by leaching in soaking solution. The results approved with (Afify et al.,2012). The variance of the antioxidant activities of sorghum varieties could be related to the difference in their content of phenolics and to the differences of phenolics. In fact, several studies of structurally related phenolic compounds have appered differences in their antioxidant activity (Rice-Evans 1999 ; Bors 2001 ; Ramadan et al.,2012) they reported that, the decrease in antioxidants activity after germination may be as a cause of activation of some enzymes and other metabolic processes during germination who crak the antioxdants compounds, which leads to loss of antioxidants activity in sorghum grains. After fermentation for $12 \mathrm{~h}$ Giza 15 and after wet cooking for $2 \mathrm{~h}$ antioxidant activity were increase by $47 \%$ and $58 \%$, respectively. While the decrease of antioxidant activity for these process of Assuit 14 was 5.4\% and $6.4 \%$,respectively. Fermentation with Saccharomyces cerevisiae had a positive influence on DPPH inhibitory effect in Giza15 sorghum grains, this increased may be as a result of the increase of total phenolic compounds that was appeared in this study for Giza 15 variety by fermentation process or for the production of other compounds from yeast during fermentation such as ascorbic acid, carotenoids and tocopherols, These results approved with( Đorđević et al.,2010). On the other hand the increase of antioxidants activity after Giza 15 cooking ( $58 \%$ ) may be result of the thermal processing known to alter the antioxidant profile and generate more antioxidants that contribute in antioxidant activity. Increase in antioxidant activity due to thermal processing, caused by the formation of Maillard browning pigments which enhanced the antioxidant activity approved with (Sharma et al.,2012).The decrease of antioxidant activity after Assiut 14 cooking may be cause of some antioxidants components had been lost in boiling water such as polyphenol compounds. These results are in the same line with that of (de Morais Cardoso et al.,2014).

Table 8. Effect of soaking on antioxidant activity in sorghum.

\begin{tabular}{|c|c|c|c|c|c|c|c|c|c|}
\hline \multirow[b]{2}{*}{$\begin{array}{l}\text { Sorghum } \\
\text { Cultivars }\end{array}$} & \multicolumn{9}{|c|}{$50 \%$ DPPH radical scavenging activity (EC $50 \mathrm{mg}$ ) } \\
\hline & $\begin{array}{c}\text { Control } \\
\text { T0 }\end{array}$ & $\begin{array}{c}\text { Soaking in } \\
\text { water } \\
\text { T1 }\end{array}$ & $\begin{array}{c}\% \\
\text { Reduction }\end{array}$ & $\begin{array}{c}\text { Soaking in } \\
\text { KOH } 2 \% \\
\text { T2 }\end{array}$ & $\begin{array}{c}\% \\
\text { Reduction }\end{array}$ & $\begin{array}{c}\text { Soaking in } \\
\text { NH4OH } 30 \% \\
\text { T3 }\end{array}$ & $\begin{array}{c}\% \\
\text { Reduction }\end{array}$ & $\begin{array}{c}\text { Soaking in } \\
\text { NaOH } 2 \% \\
\text { T4 }\end{array}$ & $\begin{array}{c}\% \\
\text { Reduction }\end{array}$ \\
\hline Giza 15 & $22.15^{\mathrm{f}}$ & $40.55^{\mathrm{c}}$ & 83 & $32.66^{\mathrm{d}}$ & 47.5 & $42.19^{\mathrm{b}}$ & 90.5 & $52.04^{\mathrm{a}}$ & 135 \\
\hline Assuit 14 & $7.544^{\mathrm{h}}$ & $40.334^{\mathrm{b}}$ & 434 & $41.233^{\mathrm{a}}$ & 446 & $37.95^{\mathrm{c}}$ & 403 & $32.232^{\mathrm{d}}$ & 327 \\
\hline
\end{tabular}

Table 9. Effect of germination, fermentation and wet cooking on antioxidant activity in sorghum.

\begin{tabular}{lcccccccc}
\hline $\begin{array}{l}\text { Sorghum } \\
\text { Cultivars }\end{array}$ & $\begin{array}{c}\text { Control } \\
\text { T0 }\end{array}$ & $\begin{array}{c}\text { Germination } \\
\text { for 38h T5 }\end{array}$ & $\begin{array}{c}\text { \% } \\
\text { Reduction }\end{array}$ & $\begin{array}{c}\text { Fermentation } \\
\text { for 12h T6 }\end{array}$ & $\begin{array}{c}\text { \%o } \\
\text { Reduction }\end{array}$ & $\begin{array}{c}\text { Wet Cooking } \\
\text { for 2h T7 }\end{array}$ & $\begin{array}{c}\text { \% } \\
\text { Reduction }\end{array}$ \\
\hline Giza 15 & $22.15^{\mathrm{f}}$ & $26.79^{\mathrm{e}}$ & 21 & $11.745^{\mathrm{g}}$ & 47 & $(+)$ & $9.305^{\mathrm{h}}$ & 58 \\
Assuit 14 & $7.544^{\mathrm{h}}$ & $16.74^{\mathrm{e}}$ & 122 & $7.95^{\mathrm{g}}$ & 5.4 & $8.026^{\mathrm{f}}$ & 6.4 \\
\hline
\end{tabular}

Values in the same row bearing different side scripts are significantly $(\boldsymbol{p} \leq \mathbf{0 . 0 5})$ different(as assessed by Duncan's multiple range test).

Relationship between antioxidant activities and phenolics content, tannin and phytic acid content.

phenolic acids, flavonoids and condensed tannins are the formsof phenolics in sorghum (Serna-Saldivar and Rooney1995). The pigmented sorghum which have (proanthocyanidins) condensed tannins(Waniska and
Rooney2000). In this study a clear relation observed among phenolic, tannin and phytic acid content and the antioxidant activity, however the sorghum variety(Assiut14) with high content of total phenolic content, tannin content and phytic acid content showed higher antioxidant activity by DPPH by $65 \%$ than sorghum variety (Giza15) low in these active 
compounds. It suggested that some groups of phenols were strong antioxidants, like condensed tannins. This relation between these active compounds and antioxidant capacity indicated that they could used as indicators for in sorghum as antioxidant activity. High antioxidant activity of black pericarp sorghums were correlated with the high pigment content(Awika et al.,2004). Tannins in sorghum are of condensed type, sorghums containing tannins have higher antioxidant capacity than, most non-tannin sorghums because it is able to bind the free radicals Awika et al.,2004). Different genotypes of sorghum with a wide range of phenol profiles have been known as strong free radical scavengers. (Dykes 2008).

(Hagerman et al.,1998) found that The efficiency of sorghum tannin was 15 to 30 times higher than simple phenol concerning peroxyl radical quenching. The antioxidant activity of the colorless phenols may be detrmined by DPPH assay because their reaction with DPPH is slow. Hence it is important to consider color of sorghum as an indicator of antioxidant activity. It is obvious also that in this study, in spite of the clear reduction of phenolic compounds, tannin and phytic acid content after some treatments (T6 and T7) the sorghum grain showed higher antioxidant activity than control. In fact, total phenol content of the examined sorghum varieties related with their DPPH antioxidant activity in some mean, which indicated that reducing possibility was not the only mechanism for the antioxidant activity of sorghum seeds, that is why samples with low concentration of total phenol, tannin or phytic acid may have remarkable activity as antioxidant. Different results of the antioxidant activity could be measured by different methods rely on different mechanisms (Sun and Ho 2005).This information may be helpful to encourage the utilization of sorghum grain in functional foods related industries.

\section{CONCLUSION}

All the studied process were able to change the content of total phenolics, tannin ,phytate and the antioxidant activity and these process had positive or negative effect. Taking together the results suggest the antioxidant activity of these tow sorghum varieties is affected by their content of phenolic compounds, phytic acid, however the sorghum (Assiut14) variety with high content of total phenolic content, tannin content and phytic acid content showed higher antioxidant activity by DPPH than sorghum (Giza15 ) variety low in these active compounds.

\section{REFERENCES}

Abdelhaleem, W.H., El Tinay, A. H., Mustafa, A. I., and Babiker, E. E. (2008).Effect of fermentation, malt-pretreatment and cooking on antinutritional factors and protein digestibility of sorghum cultivars. Pak J Nutr 7(2): 335-341.

Afify, A. E. M. M., El-Beltagi, H. S., El-Salam, S. M. A., and Omran, A. A. (2011). Bioavailability of iron, zinc, phytate and phytase activity during soaking and germination of white sorghum varieties.Plos one 6(10):e25512.
Afify, A. E. M. M., El-Beltagi, H. S., El-Salam, S. M. A., and Omran, A. A. (2012). Biochemical changes in phenols, flavonoids, tannins, vitamin E, $\beta$-carotene and antioxidant activity during soaking of three white sorghum varieties. Asian Pacific Journal of Tropical Biomedicine 2(3): 203-209.

AOAC.(2005). Association of Official Analytical Chemists.Manual of Food Analysis, 18th Ed.Of A.O.A.C. International. Published by A.O.A.C. USA.

AOAC. (1990).Official methods of analysis (15th ed.). Arlington, VA: Association of Official Analytical Chemists.

Awika, J. M., and Rooney, L. W. (2004).Sorghum phytochemicals and their potential impact on human health. Phytochemistry 65(9): 1199-1221.

Awika, J. M., Rooney, L. W., and Waniska, R. D. (2004). "Properties of 3-deoxyanthocyanins from sorghum." Journal of Agricultural and Food Chemistry 52(14): 4388-4394.

Awika, J. M., Dykes, L., Gu, L., Rooney, L. W., and Prior, R. L. (2003a). Processing of sorghum (Sorghum bicolor) and sorghum products alters procyanidin oligomer and polymer distribution and content. Journal of agricultural and food chemistry 51(18): 5516-5521.

Awika, J. M., Rooney, L. W., Wu, X., Prior, R. L., and Cisneros-Zevallos, L. (2003b).Screening methods to measure antioxidant activity of sorghum (Sorghum bicolor) and sorghum products. Journal of Agricultural and Food Chemistry 51: 6657-6662.

Babar, V. S., Chavan, J. K., and Kadam, S. S. (1988).Effects of heat treatments and germination on trypsin inhibitor activity and polyphenols in jack bean (Canavaliaensiformis L. DC). Plant Foods for Human Nutrition 38(4): 319-324.

Barroga, C. F., Laurena, A. C., and Mendoza, E. M. T. (1985). Polyphenols in mung bean (Vignaradiata (L.) Wilczek): determination and removal. Journal of Agricultural and Food Chemistry, 33(5), 1006-1009.

Beta, T., Rooney, L. W., Marovatsanga, L. T., and Taylor, J. R. N. (1999). Phenolic compounds and kernel characteristics of Zimbabwean sorghums. Journal of the Science of Food and Agriculture 79(7): 1003-1010.

Bors, W., Michel, C., and Stettmaier, K. (2001).Structure-activity relationships governing antioxidant capacities of plant polyphenols. Methods in enzymology 335: 166.

Chinedu, S., S. Yusuf., and I. Maxwell. (2010).Fermentation of sorghum using yeast (Saccharomyces cerevisiae) as a starter culture for burukutu production. Continental Journal of Biological Sciences 3: 63-74.

Cilliers, J. J., and Singleton, V. L. (1990).Autoxidative phenolic ring opening under alkaline conditions as a model for natural polyphenols in food. Journal of Agricultural and Food Chemistry 38(9): 1797-1798. 
De Morais Cardoso, L., Montini, T. A., Pinheiro, S. S., Pinheiro-Sant'Ana, H. M., Martino, H. S. D., and Moreira, A. V. B. (2014). "Effects of processing with dry heat and wet heat on the antioxidant profile of sorghum." Food chemistry, 152, 210217.

Đorđević, T. M., Šiler-Marinković, S. S., and DimitrijevićBranković, S. I. (2010).Effect of fermentation on antioxidant properties of some cereals and pseudo cereals. Food Chemistry 119(3): 957-963.

Duodu, K. G., Nunes, A., Delgadillo, I., Parker, M. L., Mills, E. N. C. and Belton, P. S. (2002).Effect of grain structure and cooking on sorghum and maize in vitro protein digestibility. Journal of Cereal Science 35:161-174.

Dykes, L. (2008). Flavonoid composition and antioxidant activity of pigmented Sorghums of varying genotypes (Doctoral dissertation, Texas A\&M University).

Dykes, L. and L. Rooney (2007). Phenolic compounds in cereal grains and their health benefits. Cereal Foods World 52(3): 105-111.

Elkhalifa, A. E. O., and Bernhardt, R. (2010). Influence of grain germination on functional properties of sorghum flour. Food Chemistry 121(2): 387-392.

El Tinay, A. H., Gadir, A. M., and Hidai, M. E. (1979).Sorghum fermented kisra bread. INutritive value of kisra. Journal of the Science of Food and Agriculture 30(9): 859-863.

Emmambux, N. M., and Taylor, J. (2003).Sorghum kafirin interaction with various phenolic compounds. Journal of the Science of Food and Agriculture 83(5): 402-407.

Eskin, N. M., and Wiebe, S. (1983).Changes in phytase activity and phytate during germination of two fababean cultivars. Journal of Food Science 48(1): 270-271.

FAO (2005).Food and Agriculture Organization "FAOSTAT." http://faostat.fao.org/faostat/.

FAO, (1997).Production Yearbook. Food and Agriculture .Organization of the United Nation. Rome, Italy 51: 59-79.

Goufo, P., and Trindade, H. (2014). Rice antioxidants: phenolic acids, flavonoids, anthocyanins, proanthocyanidins, tocopherols, tocotrienols, $\gamma \square$ oryzanol, and phytic acid. Food science \& nutrition 2(2): 75-104.

Hagerman, A. E., Riedl, K. M., Jones, G. A., Sovik, K. N., Ritchard, N. T., Hartzfeld, P. W., and Riechel, T. L. (1998).High molecular weight plant polyphenolics (tannins) as biological antioxidants. Journal of Agricultural and Food Chemistry 46(5): 1887-1892.

Hahn, D. H., Rooney, L. W., and Earp, C. F. (1984). Tannins and phenols of sorghum. Cereal foods world (USA).

Hatano, T., Kagawa, H., Yasuhara, T., and Okuda, T. (1988). Two new flavonoids and other constituents in licorice root: their relative astringency and radical scavenging effects. Chemical \& pharmaceutical bulletin 36(6): 20902097.
Katina, K., Liukkonen, K. H., Kaukovirta-Norja, A., Adlercreutz, H., Heinonen, S. M., Lampi, A. M., and Poutanen, K. (2007). Fermentation-induced changes in the nutritional value of native or germinated rye. Journal of Cereal Science 46(3): 348-355.

Kennedy, J. A., Munro, M. H. G., Powell, H. K. J., Porter, L. J., and Foo, L. Y. (1984). The protonation reactions of catechin, epicatechin and related compounds. Australian journal of chemistry, 37(4): 885-892.

Klopfesntein, C.F. and Hoseney,R.C. (1995).Nutritional : properties of sorghum and millets. In: Sorghum and Millets: Chemistry, Technology (edited by D.A.V. . Dendy) St Paul, MN: Am. Assoc. Cereal Chemists 125-168.

Liu, L., Herald, T. J., Wang, D., Wilson, J. D., Bean, S. R., and Aramouni, F. M. (2012). Characterization of sorghum grain and evaluation of sorghum flour in a Chinese egg noodle system. Journal of Cereal Science 55(1): 31-36.

Loponen, J., Mikola, M., Katina, K., Sontag-Strohm, T., and Salovaara, H. (2004).Degradation of HMW glutenins during wheat sourdough fermentations. Cereal Chemistry 81(1): 87-93.

Miller, H. E., Rigelhof, F., Marquart, L., Prakash, A., and Kanter, M. (2000). Whole-grain products and antioxidants. Cereal Food World 45: 59-63.

Mulimani, V. H., and Supriya, D. (1994). Tannic acid content in sorghum (Sorghum bicolour M.): Effects of processing. Plant Foods for Human Nutrition 46(3): 195-200.

Oboh, G. (2006). Antioxidant properties of some commonly consumed and underutilized tropical legumes. European Food Research and Technology 224(1): 61-65.

Price, M. L., Van Scoyoc, S., and Butler, L. G. (1978)A critical evaluation of the vanillin reaction as an assay for tannin in sorghum grain. Journal of Agricultural and Food Chemistry 26(5): 12141218.

Rahman, I. E. A., and Osman, M. A. W. (2011).Effect of sorghum type (Sorghum bicolor) and traditional fermentation on tannins and phytic acid contents and trypsin inhibitor activity. Journal of Food, Agriculture and Environment 9(3): 163-166.

Rahaman, S.M.A., Elmaki, H.B., Hassan,W.I., Babiker,E.E and ElTinay,A. (2005).Proximate composition, antinutritional factors and mineral content and availability of selected legumes and cereals grown in Sudan. Journal of Food Technology 3: 511-515.

Ramadan, B. R., Sorour, M. A. H., and Kelany, M. A. (2012).Changes in total phenolics and DPPH scavenging activity during domestic processing in some cereal grains. Ann. Food Sci. Technol 13: $190-196$.

Remy, S., Fulcrand, H., Labarbe, B., Cheynier, V.and Moutounet, M. (2000).First confirmation in red wine of products resulting from direct anthocyanin-tannin reactions. Journal of the Science of Food and Agriculture 80(6): 745-751. 


\section{Sorour, M. A. et al.}

Rice-Evans, C.(1999).Screening of phenolics and flavonoids for antioxidant activity. In Antioxidant Food Supplements in Human Health; Packer, L.; Hiramatsu, M.; Yoshikawa, T. Eds.; Academic Press: New York: 239-253.

Riedl, K. M., and Hagerman, A. E. (2001).Tanninprotein complexes as radical scavengers and radical sinks. Journal of agricultural and food chemistry 49(10): 4917-4923.

SAS [SAS Institute]. (2009).SAS/STAT ${ }^{\circledR}$ 9.2User's Guide. 2nd ed. Cary, NC: SAS Institute Inc.

Scalbert, A., Deprez, S., Mila, I., Albrecht, A., Huneau, J., and Rabot, S. (2000).Proanthocyanidins and human health: Systemic effects and local effects in the gut. Bio Factor 13: 115-120.

Serna-Saldivar, S., and Rooney, L. W. (1995).Structure and chemistry of sorghum and millets. In D. A. V. Dendy (Ed.), Sorghum and millets:chemistry and technology (1st ed., pp. 69-124). St. Paul, MN: American Association of Cereal Chemists, Inc.

Sharma, P., Gujral, H. S., and Singh, B. (2012).Antioxidant activity of barley as affected by extrusion cooking. Food Chemistry 131(4): 1406-1413.

Shweta, K. A., Shobha, A. U., and Padmini, G. (2010). Polyphenols and tannins in Indian pulses: Effect of soaking, germination and pressure cooking. Food Research International 43 : 526-530.

Sorour, M. A. H., Ramadan, B. R., and Hussein, A. S. I. (2003)."Changes of phytase activity, phytates and minerals content during germination and fermentation of two mung bean cultivars."Assiut Journal of Agricultural Sciences (Egypt).
Sun, T., and Ho, C. T. (2005).Antioxidant activities of buckwheat extracts. Food chemistry 90(4): 743749.

Taga, M. S., E. Miller and D. Pratt .(1984).Chia seeds as a source of natural lipid antioxidants. Journal of the American Oil Chemists' Society 61(5): 928931.

Valko, M., Leibfritz, D., Moncol, J., Cronin, M. T. D., Mazur, M., and Telser, J. (2007).Free radicals and antioxidants in normal physiological functions and human disease. The International Journal of Biochemistry and Cell Biology 39(1): 44-84.

Waniska, R. D. (2000). "Structure, phenolic compound and antifungal proteins of sorghum caryopses." In A. Chandrashekar, R. Bandyopadhyay, and A. J. Hall (Eds.).Technical and institutional options for sorghum grain mold management. Proceedings of an international consultation ( $\mathrm{pp}$. 72-106). Andhra Pradesh, India: ICRISAT.

Waniska, R. D., and Rooney, L. W. (2000).Structure and chemistry of sorghum caryopsis. In C. Wayne-Smith \& R. A. Frederiksen (Eds.), Sorghum: origin, history, technology and production (first ed., pp. 648-688). New York: John Wiley and Sons.

\footnotetext{
التغير ات التى تحدث للمركبات الفينولية والتانينات والنشاط المضاد للأكسدة لصنفين من الذرة الرفيعة نتيجة لبعض المعاملات التصنيعية

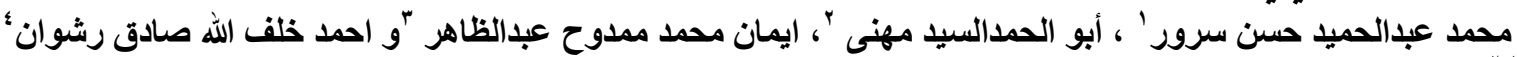

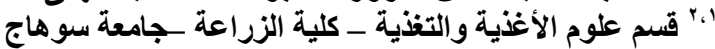

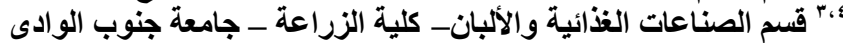

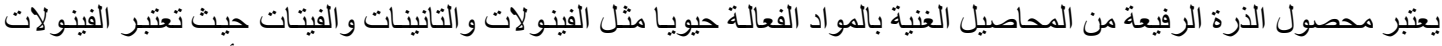

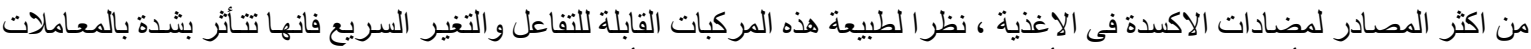

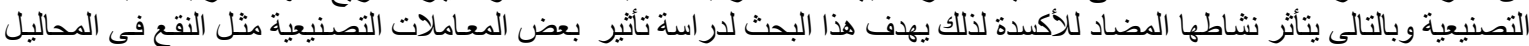

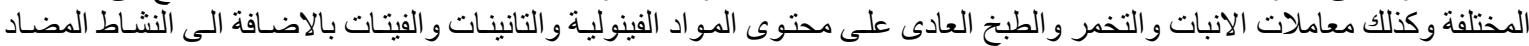

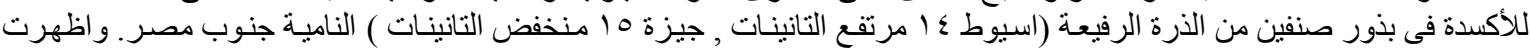

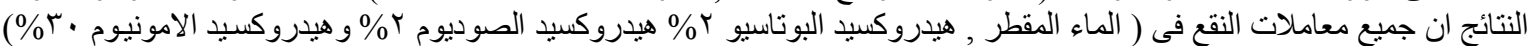

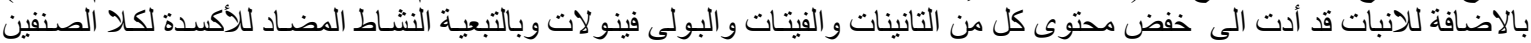

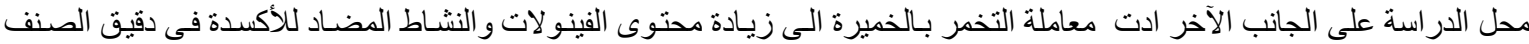

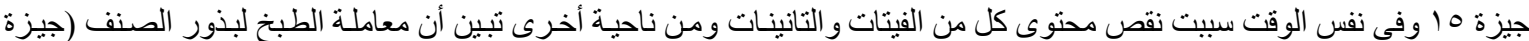

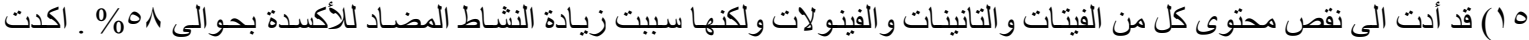

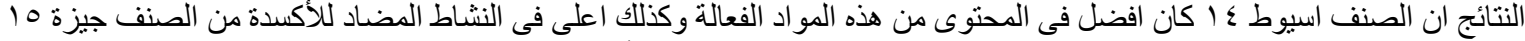

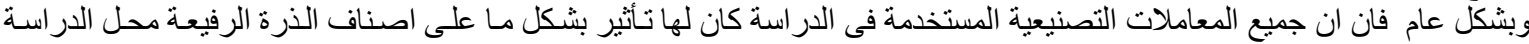
لكن هذا التأثثر قد اختلف باختناف الاصناف وباختلاف محتو اها من المواد الفعالة المدروسة.
} 